Sectional meetings of the eleven sections occupy the remainder of the week, and the final plenary session will be on May 17. Government delegates of the other American Republies will be entertained by the United States Government at an official luncheon and at a banquet. The headquarters of the Congress will be at the Pan American Union, Washington.

\section{Recent Earthquakes}

ON April 13 there were further aftershocks of the Anatolian earthquake of December 26, 1939, in the region originally affected. The shocks were strong and felt as far away as Ankara. Great damage was caused to fifteen villages, six being completely destroyed. Sixteen persons were injured and four children are believed to have been buried beneath the wreckage. In the Caucasus, according to a report in The Times, the River Kars has overflowed, causing damage to the town of Kars. It is conceivable that with such extensive disasters as Turkey has recently suffered there may be some ground tilting even as far distant from the scene of the original disaster as the Caucasus.

On the night of April 17, a severe earthquake was experienced at Patras at the entrance to the Gulf of Corinth and to the north of the Island of Morea. No information is available as to the damage caused, if any, at the time of writing. The earthquake was felt in the Agrinion district, and more severely in the Missolonghi district, where in 1824 the poet Byron died fighting for Greek independence. It is well known that minor earthquakes are common in Greece, and destructive ones are by no means uncommon. It will be remembered that on April 22, 1928, at about 20h. 14m. G.M.T., a severe earthquake somewhat to the north of Corinth partly destroyed that city. More information is required before the epicentre of the present shock can be accurately determined.

\section{The Night Sky in May}

By the middle of May, the night (sunset to sunrise, London) is of $8 \frac{1}{2}$ hours' duration. 'The moon is new on May 7 at 12h. and full on May 21 at 13h. Mars is in conjunction with the moon on May 10 and Venus on May 11. Jupiter and Saturn are now both morning stars but too close to the sun for observation. Venus is the brilliant evening star, setting less than one hour before midnight U.T. (that is, 1h. summer time). Its greatest brightness is reached about May 20, when its magnitude is $-\mathbf{4} \cdot \mathbf{2}$. Under favourable atmospheric conditions, it should be possible to see the planet in the daytime. Its time of meridian passage and altitude is given for May 5, 12, 19 and 26 $-15 \mathrm{~h}$. 3m. $\left(65 \cdot 8^{\circ}\right)$, 14h. 58m. $\left(65 \cdot 7^{\circ}\right)$, 14h. $49 \mathrm{~m}$. $\left(65 \cdot 2^{\circ}\right)$ and $14 \mathrm{~h} .35 \mathrm{~m} .\left(64 \cdot 5^{\circ}\right)$. A telescopic view of Venus at this time will show the planet as a crescent, $\frac{1}{3}$ full in the middle of May and $\frac{1}{5}$ full at the end. Venus, with respect to size and mass, is almost the twin of the earth. A dense atmosphere evidently surrounds the planet and screens its surface from observation. Direct telescopic scrutiny shows almost a complete absence of markings, but ultra-violet photographs have recorded belts and bright spots which are probably high-level phenomena. Thus the rotation period of the planet remains in doubt, though probably one rotation takes nearly a month. Venus is the cynosure of the western evening sky, but as night comes on a glance may be spared for the stars Capella, Procyon, Castor and Pollux in the west ; Regulus and Arcturus on the opposite side of the southern meridian; Spica low in the south, while Vega is above the north-eastern horizon. About May 4, members of the Eta Aquarid meteor shower (believed to be associated with Halley's Comet) may be seen in the early morning. On May 25, the 4th magnitude star, $p$ Sagittarii, is occulted by the moon, the disappearance as seen from Greenwich taking place at $1 \mathrm{~h} .23 \cdot 1 \mathrm{~m}$. at $90^{\circ}$ from the north point of the moon's image ; the reappearance being at $2 \mathrm{~h} .40 \cdot 9 \mathrm{~m}$. at position angle $253^{\circ}$.

\section{Announcements}

Dr. Stanley B. Bagley has been elected president of the Society of Glass Technology in succession to Dr. C. J. Peddle.

IT is announced in Science that Prof. F. Joliot and Madame Irene Curie-Joliot, co-workers in the Radium Institute, Paris, have been awarded the 1940 Barnard Gold Medal for "meritorious service to science" bestowed by Columbia University every five years. The medal was established by the will of Frederick A. P. Barnard, president of Columbia during 1864-1889, and is awarded "to the person, if any, whether a citizen of the United States or any other country, who within the five years next preceding has made such discovery in physical or astronomical science, or such novel application of science to purposes beneficial to the human race, as in the judgment of the National Academy of Sciences of the United States is esteemed most worthy of such honor'.

IN future the identification tag that every soldier in the German army must wear round his neck must indicate the blood group to which he belongs.

Migration during 1939 increased the population of Australia by 12,537 persons, 1,636 of these being British. German nationals-almost all refugeesnumbered 4,857. The gain to Australia of British migrants is the largest since 1929 , when the depression stopped assistance to immigrants.

According to La Riforma Medica of February 10, the annual birth-rate per 1,000 inhabitants in the chief capitals is as follows: Rome, 22; Buenos Aires, 18 ; Copenhagen, Budapest and Amsterdam, 15 ; New York, Berlin and London, 14 ; Warsaw, 13 ; Paris and Stockholm, 11; and Brussels, 10.

Erratum. Nature, January 27, p. 148, letter entitled "First Benedicks Effect in Gas-free Mercury, as Influenced by the Mean Temperature", for the formula $u=\mathrm{K} \cdot \frac{3}{\Delta t}$ read $u=K \cdot \overrightarrow{\Delta t}^{\text {a }}$. 